\title{
STRUCTURAL CHANGES AND HOW TO EXPAND THE PRODUCTIVE BASE OF THE SAUDI ECONOMY
}

\section{Mohammad H. Al-Qunaibet ${ }^{1}$, Khalid Nahar Alrwis ${ }^{2}$, Adel M. Ghamen ${ }^{2}$, Sharaf Aldin Bakri Ahamad*2, Nageeb Mohammed Aldawdahi ${ }^{2}$}

${ }^{1}$ Department of Agricultural Economics, College of food and Agricultural Sciences, Agricultural economics, King Saud University, PO Box 2460, Riyadh 11451, Saudi Arabia

${ }^{2}$ King Abdullah Ben Abdulaziz Food Security Chair, College of food and Agricultural Sciences, Agricultural economics, King Saud University, PO Box 2460 , Riyadh 11451, Saudi Arabia

Received - December 20, 2017; Revision - January 29, 2018; Accepted - February 15, 2018

Available Online - February 20, 2018

DOI: http://dx.doi.org/10.18006/2018.6(1).142.149

KEYWORDS
Investments
Structural changes
Multiplier
Production base
Saudi Arabia

\begin{abstract}
The study measures the structural changes brought in Saudi Arabia by virtue of its economic development plans in order to expand the productive base of the economy. This study, in achieving its objectives regarding standard economic analysis, made use of secondary data issued by the Saudi Arabian Monetary Agency. In the study results, the values of the Spearman and Kendall rank correlation coefficients were both positive and statistically significant; this suggests that the structural changes that took place in the Saudi economy during the execution of development plans were not substantial .It was found that during the study period, the private sector in that country accounted for $46.3 \%$ of all fixed capital, followed by the public sector $(32 \%)$ and the oil sector $(10 \%)$. The investment multiplier indicates a SAR1 million increase in fixed investment, which in turn led to increased contributions to the Saudi gross domestic product by the oil sector and the private and government sectors. Under the even redistribution in 2014 of fixed investment among the economic sectors, the oil sector is thought to have contributed $66.7 \%$ of the resulting estimated income of SAR 5,096.06 billion, followed by the government sector $(20.9 \%)$ and the private sector $(12.5 \%)$. Finally, the study results suggest that there is a need to expand the productive base by taking the following actions : (i) increasing the investment
\end{abstract}

* Corresponding author

E-mail: sharaf.bakri@gmail.com (Sharaf Aldin Bakri Ahamad)

Peer review under responsibility of Journal of Experimental Biology and Agricultural Sciences.

Production and Hosting by Horizon Publisher India [HPI] (http://www.horizonpublisherindia.in/).

All rights reserved.
All the article published by Journal of Experimental Biology and Agricultural Sciences is licensed under a Creative Commons Attribution-NonCommercial 4.0 International License Based on a work at www.jebas.org.

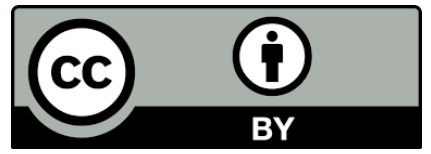


multiplier in the private sector, through the localization of technology and increasing both production and productivity, and (ii) forwarding investments in (and mobilizing resources toward) productive nonoil sectors in the Kingdom of Saudi Arabia.

\section{Introduction}

The Saudi economy has undertaken successive development plans, each of which has been based on crude oil and natural gas production. The national production of oil and gas is sine qua none for the development of the country, and their relative importance is fully recognized since 1981 . Although these two contributing nearly 57 percent in the total production of the economy. The production of oil and natural gas declined 44.7 percent in 2013; however the relative importance of manufacturing increased from $4.8 \%$ in 1981 to $10.1 \%$ in 2013 . Saudi Arabia's economy is still quite outwards-looking in terms of inputs and outputs. The increased imports are playing an important role in the supply of goods and services; is favorable for the economic development of the country. Petroleum exports naturally play an important and influential role in steering the economy, however in recent years, crude oil prices declined from USD110.30/barrel in 2012 to USD58.80/barrel in May 2015. The obligation of Saudi Arabia's OPEC commitments, oil exports are expected to decrease, inevitably impacting state economy. Thus it seems imperative to expand its productive base through non oil sector for future development plans and increase relative share in the gross domestic product (GDP).

Some studies address economic diversification and its impact on growth and development. Ghanem \& Fawaz (1998) address specific allocations of economic and agricultural resources in light of structural changes in factors within the Egyptian economy. That study showed that those structural changes were not substantial, as they acted as catalysts for growth and development; indeed, between 1976 and 1997, those changes worked in favor of Egypt's least-productive sectors. Hiti (2003) discusses the success of the Gulf Cooperation Council (GCC) in applying economic diversification policies so as to support continuing economic and structural changes, and thus accelerate both the privatization process and the processes of increasing economic cooperation and attracting foreign direct investment. Ling et al. (2005) address the degree of industrial diversity within Taiwan, and its impact on the productivity growth of the electronics industry there. They found that the degree of diversity in the country's electronics industry is much higher than that estimated for its manufacturing industries.

Goran (2013) explains that the diversification process must take into account competitiveness, innovation, and overall development. The oil sector still plays a prominent role in the economies of GCC countries, where between 2005 and 2011 the oil sector contributed about $45.6 \%$ of GDP, about $83.9 \%$ of the total value of exports, and approximately $84.2 \%$ of all government revenues. Mrzuk (2013) studied economic diversification in GCC countries, and found that they have not achieved acceptable diversity levels, relative to other rentier states. Economic diversification can be achieved through the implementation of a package of long-term policies that ensure the gradual transition from a focus on oil to economic diversification.

Aayasrh (2014) calculates the industrial diversification coefficient in Jordan. That study showed that there were differences in the degree of industrial diversity among Jordan's provinces. It recommends encouraging investment in growth-stimulating sectors, and introducing the principle of industrial diversity in the design and planning of long and short-term industrial policy. Finally, Khatib (2014) studied the impact of diversification on growth in the Saudi economy in the 1970-2011period. That study showed that, in spite of increasing the degree of diversification vis-à-vis productive activities, the rate of change in the diversification of imports and exports and in government revenues remained very weak. Additionally, having not achieved the goal of diversifying its productive base-where oil exports account for the bulk of all merchandise exports-government revenues continued to be quite dependent on oil revenues.

It is clear that there is a dearth of research on the extent of substantial structural changes in the Saudi economy, and that previous studies have not addressed the means of expanding that country's productive base in a standardized way. The current study examines the structural changes in the Saudi economy, and how it can expand its productive base; it does so, by undertaking the four objectives viz., (i) Measuring structural changes in the Saudi economy in terms of its economic development plans, (ii) Studying the current state of investment distribution and GDP among various economic sectors, (iii) Estimating the investment multiplier of various economic sectors and (iv) Studying the redirection of fixed investment and its effect on Saudi Arabia's production base.

\section{Materials and Methods}

The study achieves its econometric analysis objectives by taking two different routes, as explained below.

1- Spearman and Kendall rank correlation coefficients were used to evaluate structural changes in the Saudi economy as successive development plans were made. The 
Spearman rank correlation coefficient $\left(r_{s}\right)$ was calculated by using the following equation (Bachioua, 2011):

$r_{s}=1-\left(6 \Sigma d_{i}^{2} \div N(N-1)\right)$,

Where $d_{i}^{2}$ represents the difference between the two symmetrical ranks, and $N$ represents the number of notes (i.e., subsectors). The significance of the Spearman rank correlation coefficients was also tested, using the $t$-test as follows

$$
t=\frac{r_{s} \sqrt{N-2}}{\sqrt{1-r_{s}^{2}}} .
$$

The Kendall rank correlation coefficient $(\pi)$ was calculated by using the following equation (Kendall, 1955):

$$
\begin{gathered}
\pi=1-\frac{4 Q}{n(n-1)}=\frac{4 P}{n(n-1)}-1, \\
P=\Sigma p_{i} Q=\Sigma q_{i}
\end{gathered}
$$

Where $P$ represents the number of matching pairs, $Q$ represents the number of nonidentical pairs, $p_{i}$ represents the numbers successive to $\mathrm{R}\left(y_{i}\right)$ that are greater than $\mathrm{R}\left(y_{i}\right)$, and $q_{i}$ represents the number of ranks successive to $\mathrm{R}\left(y_{i}\right)$ that are smaller than $\mathrm{R}$ $\left(y_{i}\right)$. The significance of the Kendall rank correlation coefficients was also tested, using a distribution $(Z)$ as follows:

$$
Z=\pi \div \sqrt{\frac{2(2 N+5)}{9 N(N-1)}} .
$$

2- We used the partial adjustment model, which is a long- term dynamic model that can be formulated as follows:

$Y_{t}=a+b X_{t}+\cdots+e_{t}$

Where $Y_{t}$ represents the GDP target of various economic sectors (i.e., government, private sector, and oil sector), $X_{t}$ represents fixed investment in various sectors, and $e_{t}$ represents the random error. The form is estimated in the initial step in the short term, as follows (Abdel-Kader, 1990):

$$
Y_{t}=a \lambda+(1-\lambda) Y_{t-1}+b \lambda X_{t}+e_{t},
$$

Where $\lambda$ represents a modification coefficient ranging from 0 to 1 . We also determine the value of $\lambda$ 's speed of adjustment, and the average adjustment lag equals $(1-\lambda) / \lambda$. Finally, the current study relies on secondary data issued by the Saudi Arabian Monetary Agency (2015).

\section{Results}

\subsection{Structural changes in the Saudi economy, through economic development plans:}

In this study structural changes in the Saudi economy, as seen through its development plans was studied. It is clear from the data in Table 1 that there were fluctuations and instability in the economic size of the various sectors between 1970 and 2014, as witnessed in its economic development plans. Despite Saudi economic development plans having considered the expansion of

\begin{tabular}{|c|c|c|c|c|c|c|c|c|c|}
\hline \multirow{2}{*}{ Sector } & \multicolumn{9}{|c|}{ Economic development plans } \\
\hline & First & Second & Third & Fourth & Fifth & Sixth & Seventh & Eighth & Ninth \\
\hline Agricultural & 2.68 & 1.13 & 1.70 & 5.39 & 5.79 & 5.70 & 4.72 & 2.82 & 1.98 \\
\hline Crude oil, natural gas, and oil refining & 56.98 & 55.23 & 46.94 & 23.52 & 34.50 & 32.79 & 38.69 & 48.89 & 46.47 \\
\hline Mining activities and other quarrying & 0.18 & 0.34 & 0.36 & 0.52 & 0.40 & 0.39 & 0.36 & 0.35 & 0.37 \\
\hline Industrial sector (without oil refining) & 1.51 & 2.07 & 2.87 & 5.91 & 5.58 & 6.99 & 7.04 & 6.89 & 7.76 \\
\hline Electricity, gas, and water & 6.57 & 0.71 & 0.42 & 1.56 & 1.99 & 1.89 & 1.80 & 1.22 & 1.16 \\
\hline construction & 3.14 & 8.63 & 8.79 & 8.56 & 6.61 & 6.69 & 5.95 & 4.63 & 4.69 \\
\hline Wholesale and retail trade, restaurants, and hotels & 3.46 & 4.07 & 5.68 & 8.47 & 6.45 & 6.83 & 6.95 & 7.17 & 8.57 \\
\hline Transport, storage, and communications & 3.36 & 2.58 & 3.41 & 5.36 & 4.60 & 4.51 & 4.23 & 4.10 & 4.84 \\
\hline Finance, insurance, and real estate & 13.33 & 17.81 & 17.83 & 17.71 & 12.38 & 12.02 & 10.86 & 8.95 & 9.12 \\
\hline Services (collective, social, and personal) & 0.96 & 1.75 & 2.23 & 4.57 & 3.66 & 3.50 & 3.11 & 2.02 & 1.78 \\
\hline Other sources* & 8.01 & 6.02 & 10.13 & 18.95 & 18.44 & 19.08 & 16.65 & 13.31 & 13.63 \\
\hline
\end{tabular}
the country's productive base a strategic goal, the oil sector continues to rank first in terms of its share in GDP: it decreased from $56.98 \%$ during the first development plan to $23.52 \%$ during

Table 1 Relative share of various sectors in the Saudi gross domestic product (\%),across various economic development plans

Includes government services and import duties.

Source: Collected and calculated from the Saudi Arabian Monetary Agency (2015).

Journal of Experimental Biology and Agriculture Science

http://www.jebas.org 
the fourth development plan, and then increased to $46.47 \%$ during the ninth development plan. The aggregate level of nonoil productive sectors did increase the relative importance of the industrial sector; however, it eroded the relative importance of the agricultural sector (from $5.79 \%$ during the fifth development plan to $1.98 \%$ during the ninth development plan), due to decreases in crop area and in the total amounts of loans and agricultural subsidies given to the farmers. Additionally, decisions were made to rationalize water consumption in the agricultural sector and the most important decision is (335 concerns with stop cultivation of wheat with in eight years). On the other hand, the relative importance of most service sectors with regards to the GDP increased, with the exception of the finance, insurance, and real estate services sector, whose share in the GDP decreased from $13.33 \%$ during the first development plan to $9.12 \%$ during the ninth development plan.

During study degree of structural change in the Saudi economy by examining the country's development plans was also accessed. Table 2 shows the ranking of Saudi Arabia's various sectors in terms of GDP contribution, while Table 3 shows that the Spearman rank correlation coefficient ranged from 0.68 to 1 . The results of a

Table 2 Rankings of sectors during Saudi Arabia's economic development plans

\begin{tabular}{|c|c|c|c|c|c|c|c|c|c|}
\hline \multirow{2}{*}{ Sector } & \multicolumn{9}{|c|}{ Economic development plans } \\
\hline & First & Second & Third & Fourth & Fifth & Sixth & Seventh & Eighth & Ninth \\
\hline Agricultural & 8 & 9 & 9 & 7 & 6 & 7 & 7 & 8 & 8 \\
\hline Crude oil, natural gas, and oil refining & 1 & 1 & 1 & 1 & 1 & 1 & 1 & 1 & 1 \\
\hline Mining activities and other quarrying & 11 & 11 & 11 & 11 & 11 & 11 & 11 & 11 & 11 \\
\hline Industrial sector (without oil refining) & 9 & 7 & 7 & 6 & 7 & 4 & 4 & 5 & 5 \\
\hline Electricity, gas, and water & 4 & 10 & 10 & 10 & 10 & 10 & 10 & 10 & 10 \\
\hline Construction & 7 & 3 & 3 & 4 & 4 & 6 & 6 & 6 & 7 \\
\hline Wholesale and retail trade, restaurants, and hotels & 5 & 5 & 5 & 5 & 5 & 5 & 5 & 4 & 4 \\
\hline Transport, storage, and communications & 6 & 6 & 6 & 8 & 8 & 8 & 8 & 7 & 6 \\
\hline Finance, insurance, and real estate & 2 & 2 & 2 & 3 & 3 & 3 & 3 & 3 & 3 \\
\hline Services (collective, social, and personal) & 10 & 8 & 8 & 9 & 9 & 9 & 9 & 9 & 9 \\
\hline Other sources ${ }^{*}$ & 3 & 4 & 4 & 2 & 2 & 2 & 2 & 2 & 2 \\
\hline
\end{tabular}

"Includes government services and import duties.

Source: Collected and calculated from data in Table 1.

Table 3 Correlation coefficients for various sectors in Saudi Arabia, among economic development plans

\begin{tabular}{|lccccc|}
\hline Economic development plans & \multicolumn{3}{c}{ Rank correlation coefficient } \\
\hline Between first and second plans & Spearman & $t$ test & Kendall & $2.57^{* *}$ \\
\hline Between second and third plans & 0.72 & $3.10^{* *}$ & 0.60 & $4.28^{* *}$ \\
\hline Between third and fourth plans & 1.00 & - & 1.00 & $3.51^{* *}$ \\
\hline Between fourth and fifth plans & 0.93 & $7.43^{* *}$ & 0.82 & $4.11^{* *}$ \\
\hline Between fifth and sixth plans & 0.99 & $22.09^{* *}$ & 0.96 & $3.64^{* *}$ \\
\hline Between sixth and seventh plans & 0.94 & $8.00^{* *}$ & 0.85 & 1.00 & $4.28^{* *}$ \\
\hline Between seventh and eighth plans & 1.00 & - & 0.93 & $3.98^{* *}$ \\
\hline Between eighth and ninth plans & 0.98 & $15.51^{* *}$ & 0.96 & $4.11^{* *}$ \\
\hline Between first and third plans & 0.99 & $22.09^{* *}$ & $3.10^{* *}$ & 0.60 & $2.57^{* *}$ \\
\hline Between first and fourth plans & 0.72 & $3.10^{* *}$ & 0.56 & $2.40^{* *}$ \\
\hline Between first and fifth plans & 0.72 & $3.18^{* *}$ & 0.60 & $2.57^{* *}$ \\
\hline Between first and sixth plans & 0.73 & $2.79^{*}$ & 0.53 & $2.27^{* *}$ \\
\hline Between first and seventh plans & 0.68 & $2.79^{*}$ & 0.53 & $2.27^{* *}$ \\
\hline Between first and eighth plans & 0.68 & $3.26^{* *}$ & 0.60 & $2.57^{* *}$ \\
\hline Between first and ninth plans & 0.74 & $3.35^{* *}$ & 0.64 & $2.74^{* *}$ \\
\hline
\end{tabular}

"Significant at the $5 \%$ level; ${ }^{* *}$ Significant at the $1 \%$ level.

Source: Collected and calculated from data in Table 2.

Journal of Experimental Biology and Agriculture Science

http://www.jebas.org 
moral test of the Spearman rank correlation coefficient - using a (t) test-showed significant correlation coefficients among the estimated development plans, at the $1 \%$ significance level. We had some reservations about the means of calculating the Spearman rank correlation coefficient: in the absence of a natural sense of the difference between the two most senior grades and the meaning of squaring the difference - including that in connection to the distribution, which is obtained from different samples - it is better to use the Kendall rank correlation coefficient, which ranged from 0.53 to 1 . The results of a moral test of the Kendall rank correlation coefficient $(z)$ showed significant correlation coefficients (at the $1 \%$ significance level) among the estimated development plans. It is clear that both the Spearman and Kendall rank correlation coefficients were positive and statistically significant, and these results imply that the structural changes that occurred in the Saudi economy during the development plans were not substantial.

3.2 Status quo of the distribution of investment and gross domestic product among various economic sectors

In studying the evolution of fixed investments across various economic sectors during the 1970-2014 period, one can see that the private sector comprised $46.3 \%$ of gross fixed capital investment, while its investment rate was $10 \%$ and its share in GDP was $37.8 \%$ (Tables 4 and 5). The government sector, in comparison, comprised $32 \%$ of gross fixed capital investment, and had an investment rate of $7.3 \%$ and a $17.4 \%$ share in GDP; for the oil sector; however, these numbers during the same period were $10 \%, 2.4 \%$, and $43.8 \%$, respectively.
Despite a $4.62 \%$ per-annum increase in its investment rate, the oil sector's relative share of GDP fell during the study period, at an annual decrease of $0.64 \%$. Despite the private sector's $2.7 \%$ perannum increase in its investment rate, its relative share in GDP increased by only $0.34 \%$ per year during the study period. These findings indicate that, despite there being a decline in investment in the public sector (at the average annual rate of $1.6 \%$ ), its relative share in GDP increased at a rate of $1.3 \%$ per annum during the 1970-2014 period

\subsection{Current valuations of fixed investments in various economic sectors}

The fixed investment multipliers of various economic sectors are calculated by estimating the economic relationship between fixed investment and GDP for various sectors, using partial adjustment in the long-term model. The data in Tables 6 and 7 indicate that the long-term flexibility of fixed investment for the oil sector, private sector, and government was $0.725,0.695$, and 0.763 ; this means that a $10 \%$ increase in fixed investment led to an increased share in GDP for the oil sector, private sector, and government, by $7.25 \%, 6.95 \%$, and $7.63 \%$, respectively. Through the first differentiation of the model in the long-term compensation-with an average fixed for the various investment sectors during the study period-it is clear that the investment multiplier refers to a SAR1-million increase in fixed investment. This led to an increase in the share in GDP by the oil sector, the private sector, and the government sectors, in the amounts of SAR14.99 million, SAR2.80 million, and SAR4.69 million, respectively.

Table 4 Descriptive analysis of share ingross domestic product and investment rates in various sectors, 1970-2014

\begin{tabular}{|c|c|c|c|c|c|}
\hline Item & Lowest value & Highest value & Average & Standard deviation & $\begin{array}{l}\text { Coefficient of } \\
\text { variation }(\%)\end{array}$ \\
\hline \multicolumn{6}{|c|}{ Relative share in gross domestic product } \\
\hline Government sector & 5.20 & 25.60 & 17.39 & 5.65 & 32.5 \\
\hline Private sector & 16.20 & 52.00 & 37.80 & 7.15 & 18.9 \\
\hline Oil sector & 22.60 & 78.40 & 43.75 & 12.38 & 28.9 \\
\hline \multicolumn{6}{|c|}{ Relative share in gross fixed capital } \\
\hline Government sector & 9.80 & 70.10 & 32.00 & 16.53 & 51.7 \\
\hline Private sector & 12.50 & 73.80 & 46.30 & 17.96 & 38.8 \\
\hline Oil sector & 2.10 & 23.00 & 10.00 & 3.69 & 36.9 \\
\hline \multicolumn{6}{|l|}{ Investment rate } \\
\hline Government sector & 2.14 & 17.97 & 7.29 & 4.02 & 55.1 \\
\hline Private sector & 4.00 & 16.18 & 10.01 & 3.57 & 35.7 \\
\hline Oil sector & 0.38 & 5.09 & 2.38 & 0.98 & 41.2 \\
\hline Total investment rate & 13.80 & 34.40 & 23.10 & 5.22 & 22.6 \\
\hline
\end{tabular}

Source: Collected and calculated by the Saudi Arabian Monetary Agency (2015). 
Table 5 Statistical analysis of the evolution of share in gross domestic product and investment rate in various sectors, 1970-2014

\begin{tabular}{|c|c|c|c|c|}
\hline Equation & $R^{2}$ & $F$ & $\begin{array}{l}\text { Growth } \\
\text { rate(\%) }\end{array}$ & Item \\
\hline \multicolumn{5}{|l|}{ Relative share in gross domestic product: } \\
\hline $\begin{array}{c}\operatorname{Ln} \hat{Y}_{1}=2.502+0.013 T \\
(22.98)^{* *}(3.04)^{* *}\end{array}$ & 0.18 & 9.23 & 1.3 & Government sector \\
\hline $\begin{aligned} \hat{Y}_{2}= & 25.859+1.326 T-0.026 T^{2} \\
& (9.58)^{* *}(4.90)^{* *}(-4.65)^{* *}\end{aligned}$ & 0.37 & 12.10 & 0.34 & Private sector \\
\hline $\begin{aligned} \hat{Y}_{3}= & 67.539-2.536 T+0.049 T^{2} \\
& (15.64)^{* *}(-5.85)^{* *}(5.42)^{* *}\end{aligned}$ & 0.46 & 17.72 & -0.64 & Oil sector \\
\hline \multicolumn{5}{|l|}{ Relative share in gross fixed capital: } \\
\hline $\begin{array}{l}\operatorname{Ln} \hat{Y}_{4}=3.715-0.017 T \\
\quad(22.71)^{* *}(-2.72)^{* *}\end{array}$ & 0.15 & 7.40 & -1.7 & Government sector \\
\hline $\begin{array}{c}\operatorname{Ln} \hat{Y}_{5}=3.128+0.026 T \\
(31.15)^{* *}(6.97)^{* *}\end{array}$ & 0.54 & 48.71 & 2.6 & Private sector \\
\hline $\begin{array}{c}\operatorname{Ln} \hat{Y}_{6}=2.359-0.005 T+\operatorname{ar}(1) \\
(9.64)^{* *}(-0.52)^{n s}(2.54)^{* *}\end{array}$ & 0.14 & 3.29 & -0.5 & Oil sector \\
\hline \multicolumn{5}{|l|}{ Investment rate: } \\
\hline $\begin{array}{l}\operatorname{Ln} \hat{Y}_{7}=2.199-0.016 T \\
\quad(12.94)^{* *}(-2.46)^{* *}\end{array}$ & 0.12 & 6.07 & -1.6 & Government sector \\
\hline $\begin{array}{l}\operatorname{Ln} \hat{Y}_{8}=1.616+0.027 T \\
\quad(25.93)^{* *}(11.42)^{* *}\end{array}$ & 0.75 & 130.52 & 2.7 & Private sector \\
\hline $\begin{aligned} \hat{Y}_{9}= & 3.862-0.166 T+0.003 T^{2} \\
& (9.96)^{* *}(-4.27)^{* *}(4.07)^{* *}\end{aligned}$ & 0.30 & 9.16 & 4.62 & Oil sector \\
\hline $\begin{array}{c}\operatorname{Ln} \hat{Y}_{11}=20.521+0.078 T \\
(9.17)^{* *}(0.93)^{n s}\end{array}$ & 0.02 & 0.86 & 7.8 & Total investment rate \\
\hline
\end{tabular}

Significant at the $1 \%$ level, ${ }^{n s}$ : not significant.

Source: Collected and calculated by the Saudi Arabian Monetary Agency (2015).

Table 6 Statistical analysis of the impact of investment on gross domestic product in various sectors, 1970-2014

\begin{tabular}{|c|c|c|c|c|c|c|}
\hline \multirow{2}{*}{ Item } & \multicolumn{2}{|c|}{$\begin{array}{l}\text { Oil sector } \\
\qquad \operatorname{Ln} \hat{\Upsilon}_{1}\end{array}$} & \multicolumn{2}{|c|}{$\begin{array}{l}\text { Private sector } \\
\qquad \operatorname{Ln} \hat{\mathrm{Y}}_{2}\end{array}$} & \multicolumn{2}{|c|}{$\begin{array}{r}\text { Government sector } \\
\operatorname{Ln} \hat{\mathrm{Y}}_{3}\end{array}$} \\
\hline & Short-term & Long-term & Short-term & Long-term & Short-term & Long-term \\
\hline$a$ & $\begin{array}{l}1.877 \\
(3.39)^{* *}\end{array}$ & 5.74 & $\begin{array}{c}1.989 \\
(3.21)^{* *}\end{array}$ & 4.887 & $\begin{array}{c}0.428 \\
(2.79)^{* *}\end{array}$ & 4.412 \\
\hline $\operatorname{Ln} Y_{t-1}$ & $\begin{array}{c}0.673 \\
(6.24)^{* *}\end{array}$ & - & $\begin{array}{c}0.593 \\
(8.84)^{* *}\end{array}$ & - & $\begin{array}{c}0.903 \\
(60.45)^{* *}\end{array}$ & - \\
\hline $\operatorname{Ln} X$ & $\begin{array}{c}0.237 \\
(2.23)^{*}\end{array}$ & 0.725 & $\begin{array}{c}0.283 \\
(6.30)^{* *}\end{array}$ & 0.695 & $\begin{array}{c}0.072 \\
(4.66)^{* *}\end{array}$ & 0.763 \\
\hline $\operatorname{ar}(1)$ & - & - & $\begin{array}{c}0.80 \\
(7.08)^{* *}\end{array}$ & - & $\begin{array}{c}0.330 \\
(2.19)^{*} \\
\end{array}$ & - \\
\hline$R^{2}$ & 0.92 & - & 0.99 & - & 0.99 & - \\
\hline$F$ & 236.92 & - & 5931.8 & - & 5059.2 & - \\
\hline D. W & 1.56 & - & 1.55 & - & 2.09 & - \\
\hline $\begin{array}{l}L M \\
\text { test }\end{array}$ & 1.30 & - & 1.47 & - & 0.70 & - \\
\hline $\begin{array}{l}\text { Arch } \\
\text { test }\end{array}$ & 0.0005 & - & 1.88 & - & 0.34 & - \\
\hline
\end{tabular}

Significant at the $1 \%$ level $;{ }^{\text {ns }}$ : not significant.

Source: Collected and calculated by the Saudi Arabian Monetary Agency (2015).

Journal of Experimental Biology and Agriculture Science http://www.jebas.org 
4 Effect of redirecting fixed investment on production base in the Saudi economy:

We studied the effects of redirecting fixed investment and doubling investments, as they are brought to bear on the production base of the Saudi economy. We did so under the following three scenarios viz., (i) Fixed investments were distributed evenly over the various economic sectors (ii) Fixed investments were distributed according to each sector's proportional share in GDP during the study period (iii) Fixed investments were distributed at rates of $60 \%, 30 \%$, and $10 \%$ to the private, public, and oil sectors, respectively. Table 8 shows that, under the first scenario (i.e., even distribution of fixed investment across the economic sectors),for the projected fixedform income in 2014 of SAR5096.06 billion, the oil sector accounted for $66.7 \%$, followed by the government sector $(20.9 \%)$ and the sector private (12.5\%). Under the second scenario (i.e., distribution of fixed investment according to each sector's proportional share in GDP during the study period), the projected fixed-form income in 2014 of SAR3391.8 billion led to a $37 \%$ increase in the oil sector's share, followed by $34.2 \%$ and $28.8 \%$ increases in the government and private sector shares, respectively. Under the third scenario, assuming a projected fixed-form income of SAR3118.8 billion in 2014, the private, oil, and government sectors would see share increases of $36.6 \%, 32.7 \%$, and $30.7 \%$, respectively. It is clear that the reorientation of fixed investment in favor of the private and government sectors would lead to a consequent expansion in the productive base, but also to a decrease in the expected income investments, owing to the private sector's small investment multiplier.

\section{Recommendations}

As discussed, the structural changes that occurred in the Saudi economy in the course of the development plans were not substantial, and the state has been dependent on oil as a main source of gross domestic product (GDP). With the decline in oil prices, the Saudi economy's exposure to economic risk has affected the country's GDP and the Saudi government's investment spending; it has also affected the number of exports and the surplusdeficit status of the state budget. It has also given rise to the impairment of the investment multiplier in the private sector.
Table 7 Estimates of investment multiplier and investment coefficient in various sectors, $1970-2014$

\begin{tabular}{|c|c|c|c|}
\hline Sector & Long-term model & $\begin{array}{c}\text { Investment } \\
\text { multiplier }\end{array}$ & $\begin{array}{l}\text { Investment } \\
\text { coefficient }\end{array}$ \\
\hline Oil & $\begin{array}{c}\hat{Y}_{1}=311.064+X^{0.725} \\
\frac{d \hat{Y}_{1}}{d X}=225.52 X^{-0.275} \\
\frac{d \hat{Y}_{1}}{d X}=225.52(19115.49)^{-0.275}\end{array}$ & 14.99 & 0.07 \\
\hline $\begin{array}{l}\text { Private } \\
\text { sector }\end{array}$ & $\begin{array}{c}\hat{Y}_{2}=311.064+X^{0.695} \\
\frac{d \hat{Y}_{2}}{d X}=92.126 X^{-0.305} \\
\frac{d \hat{Y}_{2}}{d X}=92.126(94507.07)^{-0.305}\end{array}$ & 2.80 & 0.36 \\
\hline Government & $\begin{array}{c}\hat{Y}_{3}=82.434 X^{0.763} \\
\frac{d \hat{Y}_{3}}{d X}=62.897 X^{-0.237} \\
\frac{d \hat{Y}_{3}}{d X}=62.897(57103.80)^{-0.237}\end{array}$ & 4.69 & 0.21 \\
\hline
\end{tabular}

Source: Collected and calculated from data in Table 6.

Table 8 Estimations of expected income from the redistribution of investments to various economic sectors

\begin{tabular}{|c|c|c|c|c|}
\hline Item & $\begin{array}{l}\text { Govern- } \\
\text { ment } \\
\text { sector }\end{array}$ & $\begin{array}{l}\text { Private } \\
\text { sector }\end{array}$ & Oil sector & Total \\
\hline Investment multiplier & 4.69 & 2.80 & 14.99 & - \\
\hline \multicolumn{5}{|l|}{ Equal distribution of investments in 2014: } \\
\hline $\begin{array}{l}\text { Relative importance of distribution } \\
\text { of investments (\%) }\end{array}$ & 33.3 & 33.3 & 33.3 & 100 \\
\hline $\begin{array}{l}\text { Value of investments in } \\
2014 \text { (millions of SAR) }\end{array}$ & 226693.3 & 226693.3 & 226693.3 & 680080 \\
\hline $\begin{array}{l}\text { Expected income investments } \\
\text { (millions of SAR) }\end{array}$ & 1063192 & 634741.2 & 3398133 & 5096065 \\
\hline $\begin{array}{l}\text { Relative importance of contribution } \\
\text { of sectors to expected income }(\%)\end{array}$ & 20.9 & 12.5 & 66.7 & 100 \\
\hline \multicolumn{5}{|c|}{$\begin{array}{l}\text { Distribution of investments in 2014, in accordance with the relative share of each sector } \\
\text { during the study period: }\end{array}$} \\
\hline $\begin{array}{l}\text { Relative importance of distribution } \\
\text { of investments }(\%)\end{array}$ & 36.4 & 51.3 & 12.3 & 100 \\
\hline $\begin{array}{l}\text { Value of investments in } \\
2014 \text { (millions of SAR) }\end{array}$ & 247549 & 348881 & 83650 & 680080 \\
\hline $\begin{array}{l}\text { Expected income investments } \\
\text { (millions of SAR) }\end{array}$ & 1161005 & 976867 & 1253911 & 3391783 \\
\hline $\begin{array}{l}\text { Relative importance of contribution } \\
\text { of sectors to expected income }(\%)\end{array}$ & 34.2 & 28.8 & 37.0 & 100 \\
\hline \multicolumn{5}{|c|}{$\begin{array}{l}\text { Distribution of investments in 2014, where private, government, and oil sector shares are set } \\
\text { to } 60 \%, 30 \% \text {, and } 10 \% \text {, respectively: }\end{array}$} \\
\hline $\begin{array}{l}\text { Relative importance of distribution } \\
\text { of investments }(\%)\end{array}$ & 30 & 60 & 10 & 100 \\
\hline $\begin{array}{l}\text { Value of investments in } \\
2014 \text { (millions of SAR) }\end{array}$ & 204024 & 408048 & 68008 & 680080 \\
\hline $\begin{array}{l}\text { Expected income investments } \\
\text { (millions of SAR) }\end{array}$ & 956873 & 1142534 & 1019440 & 3118847 \\
\hline $\begin{array}{l}\text { Relative importance of contribution } \\
\text { of sectors to expected income }(\%)\end{array}$ & 30.7 & 36.6 & 32.7 & 100 \\
\hline
\end{tabular}


Given these findings, we believe that expansion in the Saudi productive base requires two sets of conditions. One is a doubling of the investment in the private sector through the localization of technology and an increase in both production and productivity. The other is a reorientation towards investing in, and mobilizing resources towards, Saudi Arabia's nonoil productive sectors.

\section{Conflict of Interest}

Authors would hereby like to declare that there is no conflict of interests that could possibly arise.

\section{References}

Aayasrh TAM (2014) Industrial diversification in Jordan: his account and patterns. Jordan Journal of Economics Science 1: $109-125$.

Abdel-Kader MAQ (1990) Methods of measuring economic relations with computer mail applications, Dar Egyptian Universities, Alexandria, Egypt.

Bachioua LA (2011) Fundamentals of Statistics Concepts and Application:An Arabic Text, First Edition, Phillips Publishing, Hafner Publishing Co.

Ghanem AMK, Fawaz MM (1998) Factors affecting the allocation of economic and agricultural resources in Egypt in light of structural change, Seventh Conference of Agricultural Development Research, Faculty of Agriculture, Ain Shams University, Cairo, December 15-17, 1998. Annals of Agricultural Sciences 2: 505-537.

Goran A (2013) Economic diversification in the Gulf Cooperation Council (GCC). Journal of Industrial cooperation in the Persian Gulf, 105: 24-28.

Hiti NAR (2003) Economic diversification of the Gulf, the newspaper today, No. 11033, August 30, p. 3.

Kendall MG (1955) Rank Correlation Methods. New York.

Khatib MA (2014) Diversification and growth in the Saudi economy. The First Conference of Business Schools at Universities, Gulf Cooperation Council (GCC), Riyadh, February 16-17, 2014, Pp. 1-37.

Ling JS, Hung WM, Wang Y (2005) Industrial Diversification. Asian Economic Journal 19: 423-443.

Mrzuk A (2013) Economic diversification in the Arab Gulf countries' approach to rules and directories. Gulf Economic Magazine 24: 5-53.

Saudi Arabian Monetary Agency (2015) Annual Report Fifty-one.

Journal of Experimental Biology and Agriculture Science http://www.jebas.org 